\title{
Characteristics Surface Temperature of Solar Cell Polycrystalline Type to Output Power
}

\author{
Isworo Pujotomo ${ }^{1 .}$, Retno Aita Diantari ${ }^{2}$ \\ Electrical Engineering Departement, Faculty of Engineering, Sekolah Tinggi Teknik-PLN, Jakarta, Indonesia
}

\begin{abstract}
To meet the needs of electrical energy, there are alternative energy sources such as solar power in a form of solar power plant. An important equipment aim to handle the ef converting of solar energy into electrical energy are solar cells. The development of devices used to modify solar energy into electrical energy has been done since the mid-first half of the last century. Gradually the device is named by scientists with a photovoltaic device, or so-called solar cells (solar cell. This research tested polycrystalline solar module in sunny weather, bright cloudy and overcast. The test results show the effect of solar cell surface temperature to the value of its output power [1]. The condition of the polycrystalline solar panels will work optimally at the measured $32^{\circ} \mathrm{C}-50^{\circ} \mathrm{C}$ temperature range on the surface of the solar cell.
\end{abstract}

Keywords: output,polycrystalline,power,solar cell,weather.

\section{INTRODUCTION}

Although this time the backbone of energy in Indonesia still depends on fossil energy, even various technology applied to the utilization of clean coal as a dense medium cyclone, etc [2], Indonesia needs to prepare the other energy as a replacement for fossil. power.

Solar energy is one of the types of renewable energy sources or can be called renewable energy resources that are potentially. Solar energy can produce up to 156.486 MW, a larger number of if compared with other renewable energy sources. Indonesia is a country that is located in the path of the equator that throughout the year to get the light of the sun flowing. To fulfill energy and create a system of alternative plant i.e. solar. The utilization of this energy as a solar power generating system must also consider some factors for the optimization of solar power into electrical energy: weather's influence, humidity, temperature, the position of solar cells and wind direction which is located on the surface of the solar cell. In this bachelor theses will be discussed how the influence of temperature on performance characteristics photovoltaic polycrystalline types on solar. In order for the solar cell to become a source of energy that is useful and one of the factors, the efficiency must be high. One of the important parts in keeping the level of the high efficiencies is photovoltaic. But the fact is still less noted how to maintain the temperature of the surface layer that can interfere with the absorption of photovoltaic optimally the intensity of the light into the cell.

So that the problems in this research is not too extensive, then give the scope of the problem so that this research is more focused and focused to ease in understanding. The scope of the problem for research this time is as follows:

a. Photovoltaic testing with attention to an online resource

b. The temperature on the surface of the photovoltaic characteristics.

The problems examined in this research is whether the process of temperature changes on the surface of the photovoltaic affect power's output of solar power generating systems.

\section{CHARACTERISTIC PV POLYCRYSTALLINE}

\subsection{Solar Cell}

A device that is used to change solar energy into electrical power is called solar panel or solar cell. Solar panel's basis is formed from a very small portion of silicon that is coated with some certain chemicals. It typically has a minimum thickness of $0.3 \mathrm{~mm}$ and built from portions of semiconductor elements that contain positive and negative poles. Generally, each of them produces 0.5 -volt voltage. It is an active material (semiconductor) that utilize photovoltaic effects 
(Engineering) to alter the solar energy into electrical energy. Engineering (PV) is a semiconducting tool that can alter the light is directly to the mains clockwise (DC) using silicon crystals ( $\mathrm{Si}$ ) a thin. PV usually packed in a unit called the module. In a solar module consists of many solar cells that can be arranged in a parallel or series [3].

Solar cell is an active element (semiconductor) that utilizes photovoltaic effects (Engineering) to alter the solar energy into electrical energy [4]. Engineering (PV) is semiconductor tool that can alter the light is directly to the mains clockwise (DC) using silicon crystals (Si) a thin. PV usually packed in a unit called the module. In a solar module consists of many solar cells that can be arranged in a parallel or series.

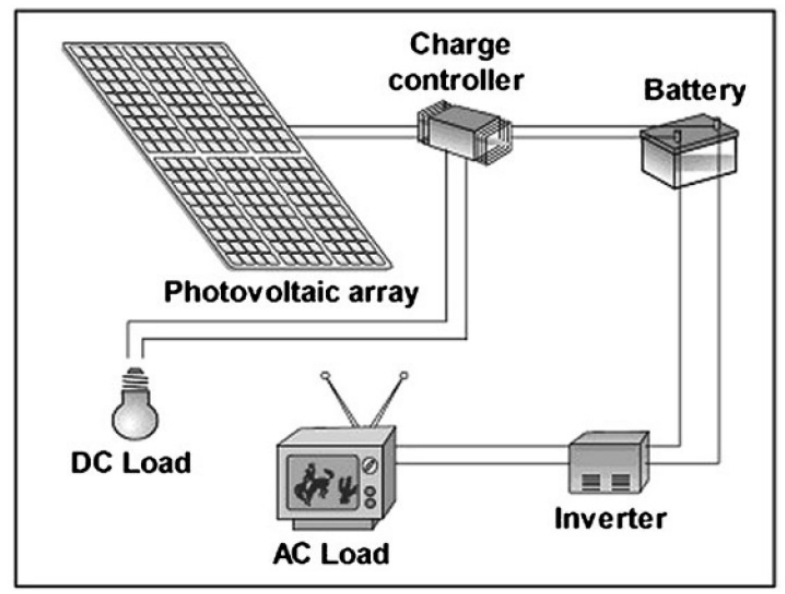

Fig 1. The solar cell scheme

The ideal position of the solar panel is facing directly into the rays of the sun (to ensure maximum efficiency). A modern solar panel has a good overheating protection in the form of thermal conductive cement. Overheating protection is important because the solar panel converts less than 20 percent of solar energy that is into electricity, while the rest will be wasted as heat and without adequate protection genesis overheating can decrease the efficiency of the solar panel significantly.

\subsection{PV Type of Polycrystalline}

This type is made from some of the barcode silicon crystals which melted and then cast in the mold that generally is square. The purity of the silicon crystal is not as high as monocrystalline polycrystalline. Its efficiency is around $13-16 \%$, but with pieces of squares, polycrystalline can be arranged more than monocrystalline meeting, reducing the space of free space between the solar cell.

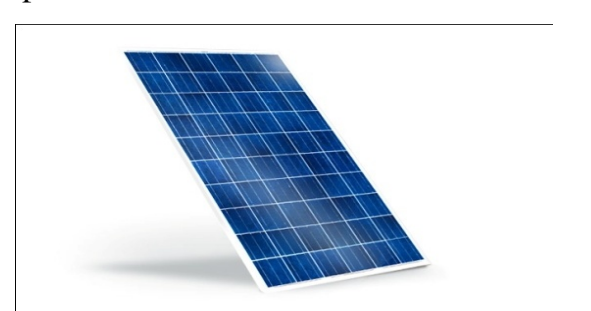

\section{Fig 2. PV Type of Polycrystalline}

Solar cells are produced from semiconductor material is silicon which act as an electrical insulator at low temperatures and as the conductor when there is energy and heat. The electrons free formed from the million photon or clash of the atoms in the interface layer (junction=0.2-0.5 micron) caused electricity. A solar cell that produces electrical energy (the sunlight energy becomes photon) does not depend on the massive wide silicone field, and constantly will produce energy ranges \pm 0.5 -volt of maximum $600 \mathrm{mV}$ on 2 ampere, with the strength of the solar radiation the sun $1000 \mathrm{~W} / \mathrm{m}^{2}=" 1$ Sun" will produce electricity (I) around $30 \mathrm{~mA} / \mathrm{cm}^{2}$ per solar cell. Graph of the connection between the current (I) and voltage (V) on the solar cell

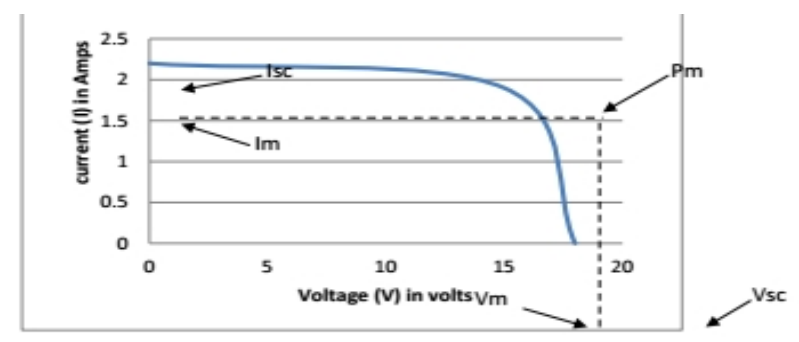

Fig 3. Curve of I - V

Description of the picture 3.:

$\mathrm{I}_{\mathrm{sc}} \quad$ : short-circuit current

$\mathrm{V}_{\mathrm{sc}} \quad$ : Open-circuit voltage

$\mathrm{V}_{\mathrm{m}} \quad$ : Voltage maximum power

$\mathrm{I}_{\mathrm{m}} \quad$ : Current maximum power

$\mathrm{P}_{\mathrm{m}} \quad$ : maximum power output from the PV array (Watts)

A solar cell can operate in a maximum if the temperature of the cells remain normal (on 25 degrees Celsius), temperature rise higher than normal temperatures on a PV cell will weaken the voltage $\left(\mathrm{V}_{\mathrm{ocs}}\right)$. Each solar cell temperature rise 1 degrees Celsius (from 25 degrees) will be reduced by around $0.4 \%$ of total energy produced 8 or lower $2 \mathrm{x}$ in other words for the cell temperature per 10 degrees $\mathrm{C}$ [5].

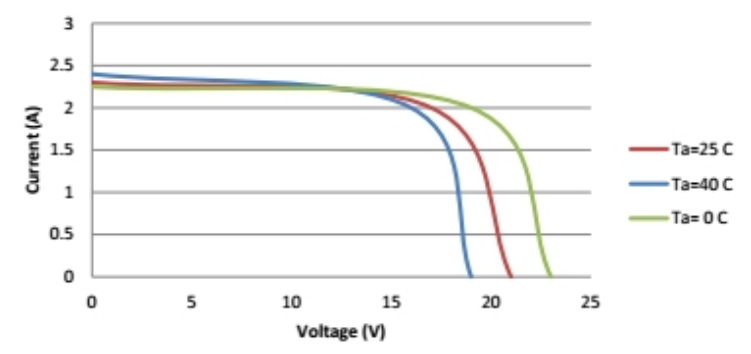

Fig. 4. Graph of the flow to temperature

Solar radiation from the sun to the earth and various locations varies, depending on the state of the solar spectrum to the earth. Solar Insolation of the sun will be much effect on current (I) little on volts. Picture 4 is a 
graph of the influence of the temperature on the solar cell in $\mathrm{W} / \mathrm{m}^{2}$.

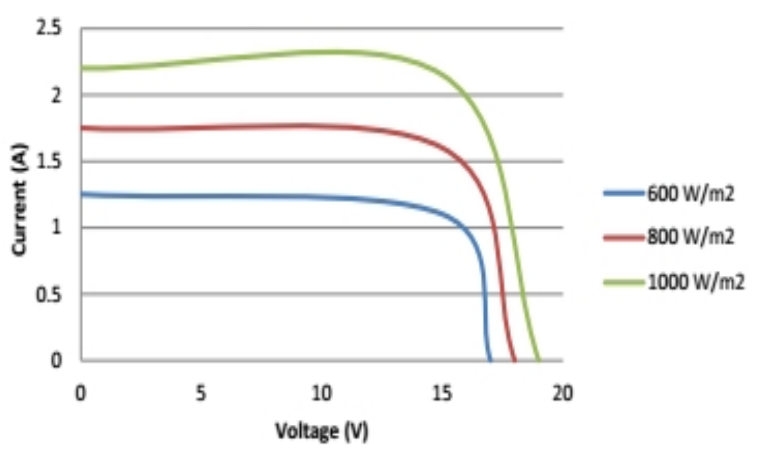

Fig. 5. Graph of current to Voltage

The speed of the blow the wind around the location of the PV array can help cool the surface temperature of the glass PV array. The atmosphere of the situation, cloudy skies, type of dust particles from the air and smoke, steam water conditioning, mist and pollution is a key factor in determining maximum results electricity from a row of PV [6].

\section{TESTING THE SOLAR PANEL}

The focus of this research is to calculate the output power efficiency of solar power of nominal value indicated on the nameplate solar cell by looking at the characteristic temperature.

Loading data related obtained in a laboratory solar power generating system at the campus of STT-PLN Jakarta conducted during 3 (three) days that started on 13 June 2017 to 15 June 2017. The research object inaugurates on Jl. Duri Kosambi, Cengkareng, the city of West Jakarta the Jakarta Provincial 11750.

The research procedure is intended to walk with good research and sequentially. With the existence of the research procedures expected research can run smoothly and can get maximum results [7].

The preparation is done to do this research covers:

1. Understand and learn the characteristics of the solar panel

2. Literature Study

3. Preparing the appliance and the material used in research

\section{RESULT AND DISCUSSION}

The following is the test result data is the author of the complete for three days starting on 13 June 2017 until 15 June 2017. Photovoltaic module with specifications [8] :
a. Model no
: SIP-20 Skytech Solar
b. Rated Power $\left(\mathrm{P}_{\max }\right)$
: $20 \mathrm{~W}$
c. Open Circuit Voltage $\left(\mathrm{V}_{\mathrm{oc}}\right)$
:21,31 V
d. Short Circuit Current $\left(\mathrm{I}_{\mathrm{oc}}\right)$
$: 1,29 \mathrm{~A}$
e. Maximum Power Voltage $\left(\mathrm{V}_{\mathrm{pm}}\right): 17,35 \mathrm{~V}$
f. Maximum Power Current $\left(\mathrm{I}_{\mathrm{pm}}\right): 1,2 \mathrm{~A}$

g. Weight

h. Dimension

: $2,5 \mathrm{Kg}$

: 350x538x35 (mm)

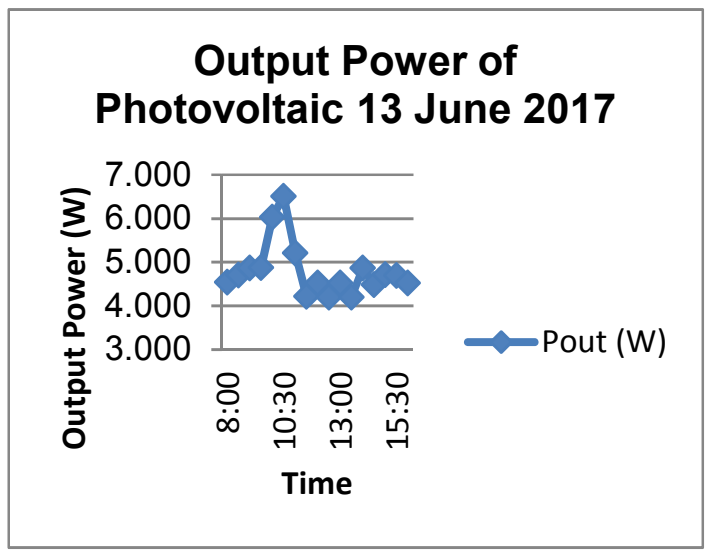

Fig. 6. Output Power Photovoltaic 13 /6/ 2017

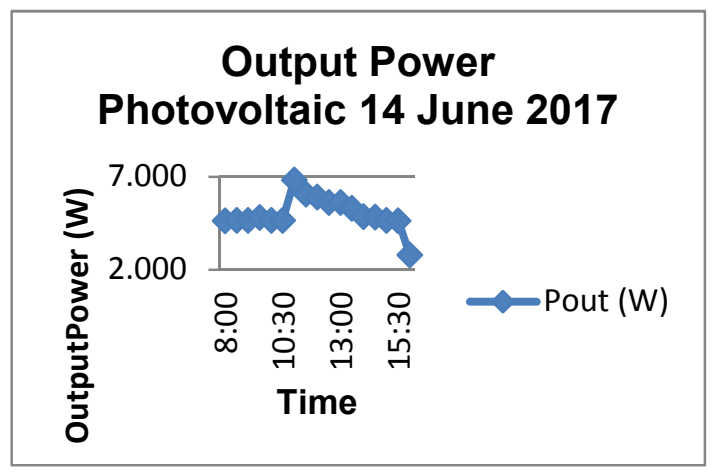

Fig. 7. Output Power Photovoltaic 14/6/ 2017

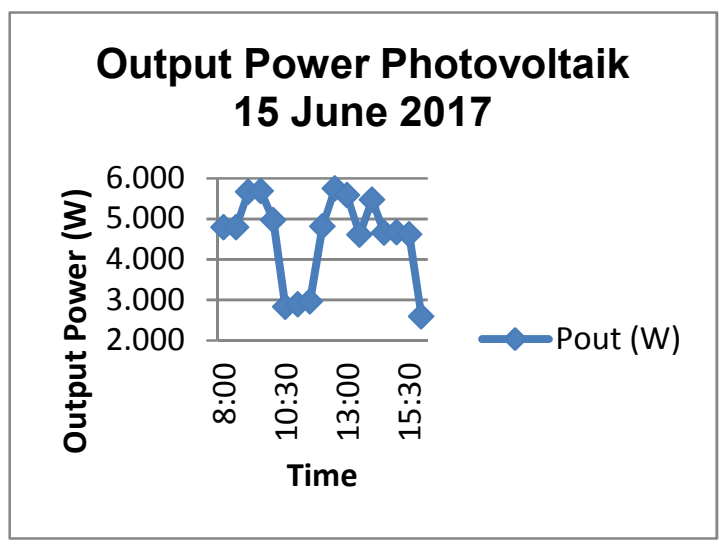

Fig. 8. Output Power Photovoltaic 15/6/ 2017

From picture 6 , picture 7 , and picture 8 . seen that the voltage will work optimally increase the value along with the increase of irradiance values in the range of the temperature of the module $32^{\circ} \mathrm{C}-50^{\circ} \mathrm{C}$. When more or less from the temperature can experience the value of the voltage drop. It can be seen that the rise in temperature resulted in an online power up. But this increase will be optimal on the range of the temperature of the module $32^{\circ} \mathrm{C}-50^{\circ} \mathrm{C}$. Due to this output power up is directly related to the revelation of the value of the voltage. Automatically the value of their own efficiencies associated with output power produced. In the testing of 
this module, the polycrystalline solar panel will show the optimal values in the range of temperature of $32^{\circ} \mathrm{C}-50^{\circ} \mathrm{C}$. When outside the range of the efficiencies tend to down this happen when the temperature increases above $50^{\circ} \mathrm{C}$ the voltage tends to come down but toss value tend to rise or constant.

\section{THE CONCLUSION}

That the rise in temperature has resulted in a reduction in the value of the voltage, but on the current value will continue to rise and constant following a rise of the value of the temperature. So the value of the output power from the solar panel will only be optimal when the temperature is $32^{\circ} \mathrm{C}-50^{\circ} \mathrm{C}$ more or less than that will decrease the value of the power of his procession. The rise in temperature caused by the increase in the value of the intensity of the sun. The maximum output power there on the test date 14 June 2017 hours 11:00 WIB at the temperature $50,59^{\circ} \mathrm{C}$ with the value of his procession of 18,98 watt power.

\section{REFERENCE}

1. T. Darmana, Nusa Penida Area Development As a Renewable Energy Resources for Bali Island, The International Conference of Vocational Studies on Applied Research (ICOVAR), 13-15 September, Semarang, Indonesia (2017).
2. I. Pujotomo, Clean Coal Technology Using Dens Medium Cyclone and Magnetite, American Scientific Publishers, ASL Volume 23, Number 3, March, pp. 2376-2378(3) (2017).

3. P. Eiffert, Building-Integrated Photovoltaic Designs for Commercial and Institutional Structures: A Source Book for Architect (PDF). pp. 60-61. (2000).

4. P. Eiffert, G. J. Kiss, Building-Integrated Photovoltaic Designs for Commercial and Institutional Structures: A Source Book for Architect. p. 59. ISBN 978-1-4289-1804-7(2000).

5. A. Henemann, "BIPV: Built- in Solar Energy". Renewable Energy Focus. Science Direct. 9 (6): 14, 16-19. doi:10.1016/S1471-0846(08)70179-3(2008).

6. S. Strong, "Building Integrated Photovoltaics $(B I P V)$ ". wbdg.org. Whole Building Design Guide. Retrieved 2011-07-26. (2010).

7. O. Temby, K. Konstantinos, H. Berton, D. Rosenbloom, G. Gibson, A. Athienitis, J. Meadowcroft, "Building-Integrated Photovoltaics: Distributed Energy Development for Urban Sustainability." Environment Magazine (2014).

8. R. A. Diantari, I. Pujotomo, Calculation Of Electrical Energy With Solar Power Plant Design, International Seminar on Intelligent Technology and its Applications (ISITIA), 28-30 July, Lombok, Indonesia. (2017). 